\title{
PENGARUH FERMENTASI MENGGUNAKAN BAKTERI ASAM LAKTAT YOGHURT TERHADAP CITARASA KOPI ROBUSTA (COFFEA ROBUSTA)
}

\section{(The Influence of Fermentation Using Bacteria Lactic Acid Yoghurt to the Flavor of Coffe Robusta (Coffea robusta))}

\author{
Abu Bakar Tawali ${ }^{1 *}$, Nurlailah Abdullah ${ }^{1)}$, dan Benny Suhardi Wiranata ${ }^{1)}$ \\ ${ }^{1 *}$ Program Studi Ilmu dan Teknologi Pangan Departemen Teknologi Pertanian Universitas Hasanuddin \\ Makassar, Indonesia \\ *)email Penulis Korespondensi: abubakar_tawali@yahoo.com
}

\begin{abstract}
ABSTRAK
Tanaman kopi (coffea $s p$ ) adalah salah satu jenis keanekaragaman hayati di Indonesia. Kopi adalah salah satu minuman paling populer di dunia. Kandungan kafein yang tinggi dalam kopi memiliki efek buruk bagi kesehatan. Salah satu jenis kopi yang digunakan dalam penelitian ini adalah Robusta, karena Kandungan kafein dalam kopi robusta lebih tinggi dari kopi arabika, sebaliknya jenis arabica mengandung lebih banyak gula dan minyak atsiri. Untuk meningkatkan kualitas kopi maka salah satu proses yang perlu diperhatikan adalah pada proses panen di masa lalu. Salah satu teknologi dalam pasca panen untuk memperbaiki cita rasa kopi adalah dengan fermentasi menggunakan bakteri asam laktat (BAL). Penelitian ini bertujuan untuk menghasilkan kopi dengan kadar kafein yang lebih rendah dengan fermentasi menggunakan BAL pada yoghurt. Parameter penelitian ini meliputi kadar kafein, tingkat ph, level air, kadar abu dan pengujian parameter seperti organolepticflavor, aroma, dan warna kopi. Percobaan terbaik yang dihasilkan dari penelitian kopi yang difermentasi dengan yogurt isolat selama 48 jam, itu mengandung kafein kadar 1,09\%, Ph 4,73, kadar air 2,34, kadar abu 3,16, parameter rasa skor 3,08, parameter aroma skor 3, dan nilai parameter warna 2,09 .
\end{abstract}

Kata Kunci : kopi, bakteri asam laktat (BAL), Kafein.

ABSTRACT
Coffee plants ( coffea sp) is one type of biodiversity in Indonesia.Coffee is one of the most popular drink in the world.The high caffeine content in coffee has bad effect for health.One kind of coffee used in this research was Robusta, because caffeine content in robusta coffee is higher than arabica coffee, otherwise the type of arabica contain more sugar and volatile oil.To improve the quality of coffee then one of the process that need attention is on the process in the past harvest. One technology in the post harvested to fix tastes coffee is by fermentation using lactic acid bacteria (BAL).This research aimed to produce coffee with the caffeine levels lower by fermentation using BAL on yoghurt. Parameter this research include caffeine level, ph level, the water level, the ashes level and testing the like parameter of organolepticflavor, aroma, and colour of the coffee. The best experiment resulting from research coffee fermented with isolate yogurt for 48 hours, it had caffeine content of $1,09 \%$, Ph of 4.73, water contentof 2.34, ashes content of 3.16, flavor parameter scored of 3.08 , aroma parameter scored of 3, and color parameter scored of 2.09.

Keywords : Coffe, lactic acid bacteria (BAL), Caffeine.

\section{PENDAHULUAN}

Kopi (Coffea sp) merupakan salah satu jenis keanekaragaman hayati yang tumbuh subur di Indonesia. Kopi 
merupakan spesies tanaman berbentuk pohon dan termasuk dalam famili Rubiaceae dan genus Coffea. Kopi merupakan salah satu minuman yang paling digemari banyak orang.

Kopi mengandung kafein yang tinggi diduga mempunyai efek yang kurang baik bagi kesehatan, terutama bagi penikmat kopi yang rentan terhadap kafein, sehingga kopi rendah kafein saat ini sangat marak diproduksi dalam negeri yang menyebabkan nilai ekonomi kopi rendah kafein lebih baik daripada kopi yang memiliki kandungan kafein tinggi.

Kandungan kafein yang terdapat pada kopi robusta sedikit lebih tinggi dibandingkan kopi arabika, sebaliknya jenis arabika lebih banyak zat gula dan minyak atsiri (Oktadina \& , Bambang dwi Argo, 2013).

Untuk meningkatkan mutu kopi, maka salah satu proses yang perlu diperhatikan adalah pada proses pasca panen. Salah satu teknologi pasca panen untuk memperbaiki cita rasa kopi adalah dengan fermentasi menggunakan bakteri asam laktat (BAL).

Biji kopi yang difermentasi basah atau semi basah sebelum dikeringkan akan meningkatkan cita rasa kopi. Selain berpengaruh terhadap cita rasa, fermentasi pada kopi juga meningkatkan nilai ekonomi kopi. Sehingga pendapatan petani kopi dapat meningkat ketimbang kopi yang tidak mengalami fermentasi.

Oleh karena itu perlu dilakukan penelitian untuk mengetahui mutu dan rasa kopi fermentasi menggunakan Bakteri Asam Laktat (BAL).Kadar kafein pada kopi robusta diketahui lebih tinggi dari jenis kopi lainnya yakni sebanyak $2.4 \%$.

Maka dari itu salah satu manfaat lain dari penelitian ini adalah untuk menurunkan kadar kafein pada kopi tersebut.

Salah satu jenis kopi yang ada di Indonesia yakni Kopi Robusta. Akan tetapi jika dibandingkan dengan jenis kopi lainnya kualitas kopi jenis ini jauh lebih rendah. Dari segi aroma, rasa maupun harga dipasaran masih dibawah dari jenih kopi Arabika dan liberika. Serta memiliki tingkat kafein yang cukup tinggi disbanding kopi lainnya. Oleh karena itu dilakukan penelitian pemberian perlakuan fermentasi dengan menggunakan yoghurt guna menurunkan kadar kafein pada kopi dan meningkatkan mutu kopi robusta. Tujuan dilakukannya penelitian ini yaitu untuk mengetahui pengaruh fermentasi terhadap citarasa kopi robusta, untuk mengetahui pengaruh lama fermentasi terhadap mutu seduhan kopi dan untuk mengetahui kadar kafein kopi robusta setelah proses fermentasi yoghurt dan Sebagai bahan acuan kepada masyarakat mengenai cita rasa kopi robusta setelah perlakuan fermentasi oleh bakteri Bakteri Asam Laktat serta sebagai informasi tambahan tentang fermentasi kopi menggunakan yoghurt pada seduhan kopi.

\section{METODOLOGI PENELITIAN}

\subsection{Alat}

Alat-alat yang digunakan di antaranya adalah wadah baskom, gelas, sendok, oven vakum, timbangan digital, pengaduk, penggiling kopi, blower, oven, desikator, mikro pipet, tabung reaksi, labu khjedall, labu ukur, labu takar, labu semprot, erlenmeyer, cawan porselin, gegep, tanur, corong, dan pipet pengisap.

\subsection{Bahan}

Bahan yang digunakan dalam penelitian ini adalah kopi dari jenis arabika dan robusta. Aluminium foil, kertas label, plastik. Bahan kimia untuk analisis yaitu: chloroform, $\mathrm{MgO}, \mathrm{KOH}, \mathrm{H} 2 \mathrm{SO} 4, \mathrm{H} 3 \mathrm{SO} 3$ $2 \%, \mathrm{NaOH} 30 \%$, HCL $0,01 \mathrm{~N}$, aquades, air.

\subsection{Prosedur Penelitian}

Prosedur penelitian yaitu dilakukan preparasi biji kopi robusta yang telah kering dan terpisah dari kulit tanduk. Selanjutnya sebanyak 250 gr kopi robusta dimasukan kedalam larutan yogurt hingga terendam sempurna atau sebanyak $450 \mathrm{ml}$ selama 12 jam, 24 jam, 36 jam, dan 48 jam. Setelah perendaman selesai kemudian dijemur dipanas matahari selama 6 jam dan 
dilanjutkan dengan pengeringan pada blower selama 7 jam dengan suhu $40^{\circ} \mathrm{C}$. Pada biji kopi selanjutnya disangrai selama 15 menit agar kopi matang sempurna, lalu dilakukan penghalusan menggunakan grinder. Setelah itu dilakukan proses pengujian kafein, $\mathrm{pH}$, kadar air, kadar abu dan pengujian organoleptik yang meliputi aroma, warna dan rasa.

\subsubsection{Pengolahan dan analisis data}

Pengolahan data dalam penelitian ini menggunakan metode Analisa Deskriptif Kuantitatif yang memberikan gambaran dari nilai rata-rata (mean) hasil pengujian sampel.

Perlakuan yang digunakan pada penelitian ini yaitu

A0 :Tanpa Perlakuan

A1 :Biji kopi difermentasi dengan isolat yougurt selama 12jam

A2 :Biji kopi difermentasi dengan isolat yougurt selama 24jam

A3 :Biji kopi difermentasi dengan isolat yougurt selama $36 \mathrm{jam}$

A4 :Biji kopi difermentasi dengan isolat yougurt selama 48 jam

Penelitian ini dilakukan dengan menggunakan3 kali ulangan kemudian apabila hasilnya berbeda nyata dilanjutkan dengan uji Duncan.

Pengamatan dan pengukuran data dilakukan setiap 7 hari selama 21 hari dengan cara analisa sesuai dengan parameter sebagai berikut : Uji organoleptik diuji berdasarkan uji hedonik (warna, aroma, rasa, tekstur), Kadar Kafein diuji berdasarkan metode Bailey-Andrew, (Hodgson \& Levi, 1987), Penentuan pH diuji menggunakan $\mathrm{pH}$ meter, Kadar air diuji berdasarkan metode oven (Sudarmadji, Haryono, \& Suhardi, 1997), Kadar abu diuji berdasarkan metode tanur (Sudarmadji et al., 1997)

\section{HASIL DAN PEMBAHASAN}

\subsection{Analisa Organoleptik}

\subsubsection{Rasa}

Rasa merupakan salah satu faktor yang mempengaruhi penerimaan seseorang terhadap suatu makanan. Rasa secara umum dapat dibedakan menjadi asin, manis, pahit dan asam (Winarno, 2004). Rasa merupakan parameter yang sangat menentukan kualitas suatu produk, apakah produk tersebut mampu diterima oleh produsen atau tidak. Oleh karena itu rasa menjadi faktor yang sangat penting bagi suatu produk yang dihasilkan.

Tingkat kesukaan panelis terhadap rasa kopi fermentasi dengan menggunakan yogurt setelah diseduh yaitu 3,7 untuk perlakuan kontrol, 3,2 untuk fermentasi 12 jam, 2,7 untuk fermentasi 24 jam, 2,6 untuk fermentasi 36 jam dan 3,8 untuk fermentasi selama 48 jam (Gambar 1). Hal ini menunjukkan bahwa rasa kopi fermentasi dengan menggunakan yogurt yang paling disukai panelis yaitu pada perlakun tanpa fermentasi, fermentasi 12 jam dan fermentasi selama 48 jam.

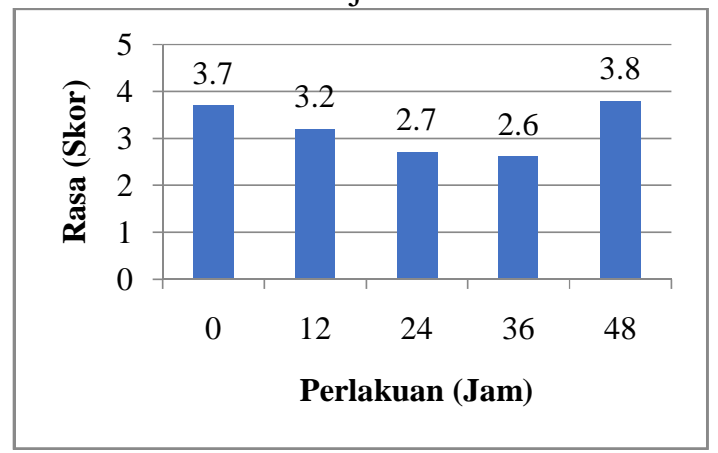

Gambar 1 Hubungan antara Fermentasi Yogurt terhadap Rasa Kopi

Tingkat kesukaan panelis terhadap rasa kopi fermentasi dengan menggunakan yoghurt berdasarkan Gambar 6 dengan skor 2,6 sampai 3,8 masuk dalam skala agak suka. Hasil analisa sidik ragam untuk rasa kopi fermentasi dengan menggunakan yogurt yaitu berpengaruh nyata $(\mathrm{p}<0,05)$ (Lampiran 2). Setelah dilakukan uji lanjut Duncan, semua perlakuan berbeda nyata pada taraf $5 \%$.

Rasa kopi fermentasi dengan menggunakan yogurt dipengaruhi oleh komponen non volatil yang terdapat dproses penyanggraian. Proses 
penyanggraian menyebabkan aroma volatil pada kopi menguap.

Rasa keasaman (acidity) dan rasa pahit (bitternes) berasal dari komponen non volatil pada kopi. Rasa pahit pada kopi juga berasal dari senyawa kafein pada kopi. Hal ini sesuai dengan (Oktadina \& , Bambang dwi Argo, 2013), keasaman dan rasa pahit terbentuk dari komponen non volatil dalam kopi. Sedangkan kafein penyumbang rasa pahit pada kopi bubuk.

\subsubsection{Aroma}

Tingkat kesukaan panelis terhadap aroma kopi fermentasi dengan menggunakan yogurtsetelah diseduh yaitu 3,5 untuk perlakuan kontrol, 2,9 untuk fermentasi 12 jam, 2,4 untuk fermentasi 24 jam, 2,1 untuk fermentasi 36 jam dan 3 untuk fermentasi selama 48 jam. Hal ini menunjukkan bahwa aroma kopi fermentasi dengan menggunakan yogurt yang paling disukai panelis yaitu pada perlakun tanpa fermentasi.

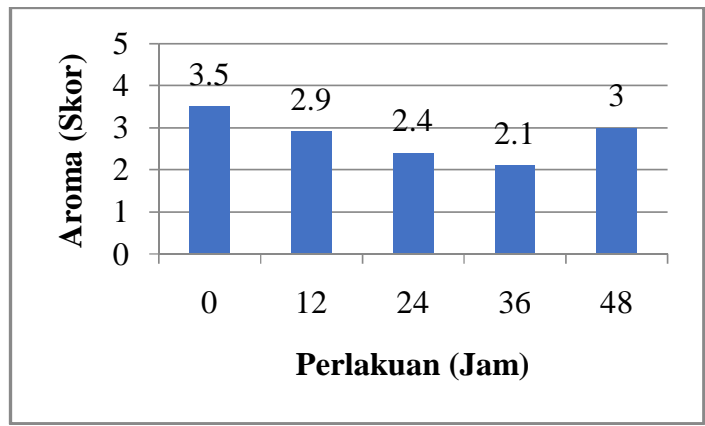

Gambar 2 Hubungan antara Kopi Fermetasi Yogurt terhadap Aroma Kopi

Tingkat kesukaan panelis terhadap aroma kopi fermentasi dengan menggunakan yogurt setelah diseduh berdasarkan Gambar 5 dengan skor 2,1 sampai 3,5 masuk dalam skala tidak suka sampai agak suka. Hasil analisa sidik ragam untuk rasa kopi fermentasi dengan menggunakan yogurt yaitu berpengaruh nyata $(\mathrm{p}<0,05)$. Setelah dilakukan uji lanjut Duncan, semua perlakuan berbeda nyata pada taraf $5 \%$. Aroma pada kopi fermentasi dengan menggunakan yogurt disebabkan oleh proses penyanggraian pada kopi. Proses penyanggraian menyebabkan senyawa volatil menguap.
Selama proses penyanggraian terdapat indikasi terelepasnya senyawa volatil dari kopi sehingga menimbulkan aroma keharuman dari kopi itu sendiri. bahwa aroma pada kopi berkaitan langsung dengan proses penyanggraian yang menyebabkan senyawa volatil pada kopi menguap dan membangun keharuman dari kopi itu sendiri.

\subsubsection{Warna}

Tingkat kesukaan panelis terhadap warna kopi fermentasi menggunkan yogurt yang dihasilkan yaitu 3,5 untuk perlakuan kontrol, 2,7 untuk fermentasi selama 12 jam, 2,9 untuk fermentasi 24 jam, 1,7 untuk fermentasi 36 jam, dan 2,7 untuk fermentasi selama 48 jam.

Hal ini menunjukkan bahwa warna kopi fermentasi dengan menggunakan yogurt yang paling disukai panelis yaitu warna kopi tanpa fermentasi (perlakuan kontrol).

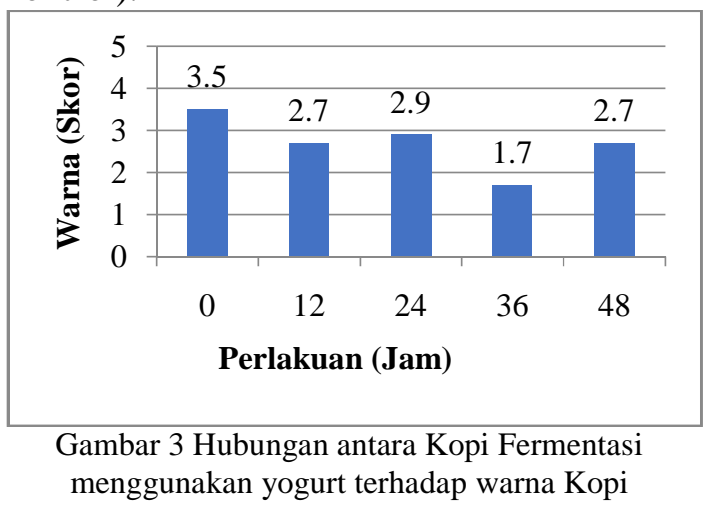

Tingkat kesukaan panelis terhadap warna kopi fermentasi dengan menggunakan yogurt setelah diseduh dengan skor 1,7 sampai 3,5 masuk dalam skala tidak suka sampai agak suka.

Hasil analisa sidik ragam untuk warna kopi fermentasi dengan menggunakan yogurt yaitu berpengaruh nyata $(\mathrm{p}<0,05)$. Setelah dilakukan uji lanjut Duncan, semua perlakuan berbeda nyata pada taraf $5 \%$. Warna pada kopi fermentasi dengan menggunakan yogurt dipengaruhi oleh beberapa faktor seperti proses roasting, adanya reaksi mailard dan juga pengaruh daro senyawa yang terkandung didalam kopi itu sendiri. 
Senyawa tanin pada kopi dapat menyebabkan terjadinya pencoklatan dan warna yang terbentuk pada bubuk kopi juga sangat ditentukan oleh reaksi Maillard, karena dari reaksi ini terjadi kondensasi antara asam amino atau protein dengan adanya jumlah gula.

\subsection{Kadar kafein}

Kafein adalah senyawa alkaloid xantina berbentuk kristal dan berasa pahit yang bekerja sebagai obat perangsang psikoaktif dan diuretik ringan. Kafein dijumpai secara alami pada bahan pangan seperti biji kopi, daun teh, dan mate.

Biji kopi mengandung kafein lebih banyak yaitu sekitar 1,6\%-2,5\% dibanding dengan daun teh dan mate sehingga efek senyawa alkaloidxantina ini lebih cepat terlihat bila mengonsumsi kopi dibandingkan mengonsumsi bahan pangan lainnya.

Pengolahan kopi secara basah dilakukan dengan perendaman selama 3640 jam akan mengakibatkan kadar kafein menurun akibat adanya pengolahan dan peminimalisiran kadar kafein secara konvensional maupun secara enzimatis.

Hasil analisa kadar kafein dalam bentuk bubuk pada fermentasi perlakuan kontrol yaitu 3,03 \%, perlakuan fermentasi 12 jam 2,34 \%, fermentasi 24 jam 1,93\%, fermentasi 36 jam $1,23 \%$ dan untuk fermentasi 48 jam yaitu $1,09 \%$. Hal ini menunjukkan bahwa kadar kafein senantiasa berkurang seiring dengan semakin lamanya kopi difermentasi.

Hasil analisa sidik ragam menunjukkan bahwa waktu fermentasi yang diberikan pada pembuatan kopi robusta yaitu berpengaruh nyata $(\mathrm{p}<0,05)$ terhadap kadar kafein. Setelah dilakukan uji lanjut Duncan, semua perlakuan berbeda nyata pada taraf $5 \%$.

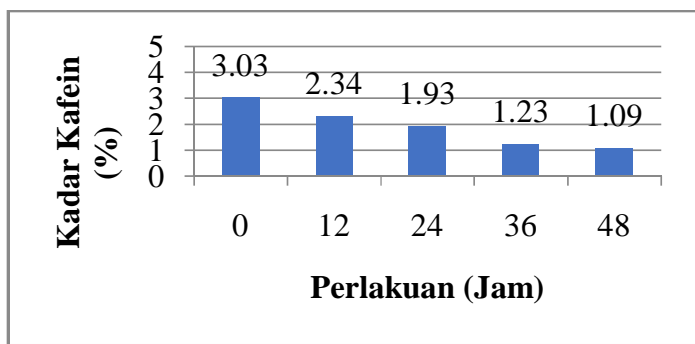

Gambar 4 Pengaruh Lama Fermentasi terhadap

Kadar Kafein Kopi Robusta yang dihasilkan.

Kadar Kafein tertinggi yaitu pada kopi robusta dengan menggunakan yogurt yang tidak difermentasi (perlakuan kontrol). Sedangkan kadar kafein terendah yaitu pada sampel kopi dengan lama fermentasi 48 jam. Semakin lama waktu fermentasi yang diberikan maka semakin rendah kadar kafein kopi. Melalui metode fermentasi dengan bakteri asam laktat Lactobacillus Bulgaricus, kandungan kafein yang ada pada kopi diurai menjadi senyawa ester. Kafein termasuk golongan senyawa alkaloid yang diuraikan menjadi ester berupa asam klorogenat melalui proses esterifikasi sehingga jumlahnya dalam kopi menjadi berkurang atau disebut juga dengan dekafeinase.

Esterifikasi menyebabkan terjadinya pemecahan senyawa kompleks kafein menjadi asam klorogenat. Senyawa kafein menjadi bebas dengan ukuran dan berat molekulnya menjadi kecil sehingga menjadi lebih mudah bergerak berdifusi melewati dinding sel dan larut dalam air. Terlepasnya asam klorogenat dari kafein kemudian diikuti dengan dekomposisi asam klorogenat menjadi senyawa organik lain hingga kemudian larut dalam media fermentasi. Makin lama proses pelarutan maka makin banyak asam klorogenat yang larut dalam media fermentasi. Penurunan kadar kafein pada kopi berbanding lurus dengan waktu fermentasi, semakin lama fermentasi maka semakin besar tingkat penurunan kafein pada kopi. Hal ini sesuai dengan (Kristiyanto \& Pranoto, 2013), yang menyatakan bahwa kafein yang merupakan senyawa alkaloid mengalami proses esterifikasi dengan alkohol. 


\subsection{Kadar pH}

Hasil analisa $\mathrm{pH}$ pada fermentasi perlakuan kontrol setlah diseduh yaitu $5,85 \%$, perlakuan fermentasi 12 jam $5,09 \%$, fermentasi 24 jam 5,13\%, fermentasi 36 jam 4,98 \% dan untuk fermentasi 48 jam yaitu $4,73 \%$. Hal ini menunjukkan bahwa nilai $\mathrm{pH}$ senantiasa menurun dengan bertambahnya waktu fermentasi. Hal ini menunjukan bahwa kadar keasaman pada kopi semakin meningkat. Hasil analisa sidik ragam menunjukkan bahwa waktu fermentasi yang diberikan pada pembuatan kopi robusta yaitu berpengaruh nyata $(\mathrm{p}<0,05)$ terhadap kadar $\mathrm{pH}$. Setelah dilakukan uji lanjut Duncan, semua perlakuan berbeda nyata pada taraf $5 \%$.

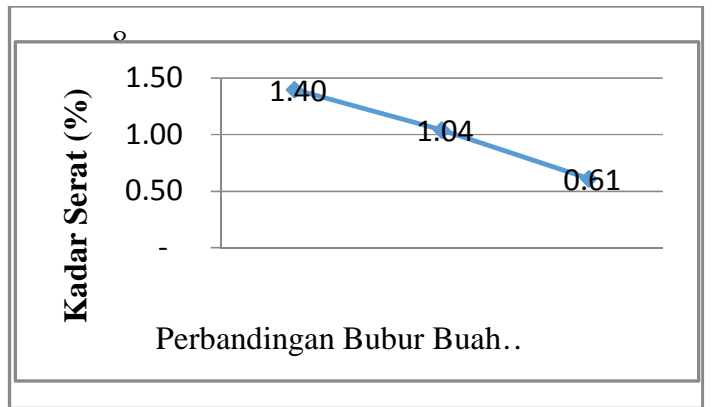

Gambar 5 Pengaruh Lama Fermentasi dengan menggunakan yogurt. terhadap $\mathrm{pH}$ Kopi Robusta

Penurunan $\mathrm{pH}$ terjadi tersebut disebabkan adanya akumulasi asam-asam organik dan peningkatan jumlah proton $\mathrm{H}+$ sebagai hasil dari metabolisme bakteri akibat penguraian asam-asam amino. Asam organik merupakan senyawa metabolit yang terbentuk sebagai aktivitas metabolisme bakteri pembentuk asam terutama bakteri asam laktat dan bakteri asam asetat. Pada umumnya semakin meningkatnya kandungan asam suatu bahan, maka nilai $\mathrm{pH}$ akan semakin menurun

Sedangkan kondisi nilai $\mathrm{pH}$ yang meningkat kembali pada jam ke-24 disebabkan karena ketidakseimbangan kinerja mikroba yang diakibatkankan suhu lingkungan yang tidak stabil.
Proses fermentasi senyawa-senyawa organik yang diuraikan oleh mikroba telah habis pada jam ke- 24 dan disini mulai terbentuk ester-ester karboksilat (seperti asam methyl butanoat, asam cyclohexanoat dan senyawa organik yang mengandung belerang) yang menyebabkan biji kopi mengalami kebusukan (cacat stinker) sehingga meningkatkan nilai $\mathrm{pH}$.

Proses dekafeinasi yang terjadi pada biji kopi juga mempengaruhi peningkatan keasaman. Nilai keasaman atau $\mathrm{pH}$ biji sangat dipengaruhi oleh kandungan senyawa asam-asam volatil dan non volatile.

Senyawa asam volatil seperti asam asetat, butirat, propionate dan valerat mempunyai titik didik rendah dan mudah terurai selama proses dekafeinasi, senyawa asam non volatil terdiri dari asam klorogenat, oksalat, malat, sitrat dan tartrat akan terurai membentuk senyawa lain. Terlepasnya asam klorogenat dari kafein diikuti dengan dekomposisi asam klorogenat menjadi senyawa organik kuinat dan larut dalam air.

Kadar asam klorogenat yang semula $7,6 \%$ turun mencapai dibawah $1 \%$. Asam klorogenat akan terurai menjadi asam kuinat dan larut dalam air sehingga akan meningkatkan $\mathrm{pH}$ pada biji kopi selama proses dekafeinasi. Hal ini sesuai dengan (Charley, 1998) asam klorogenat akan terurai menjadi asam kuinat dan larut dalam air. Dengan demikian nilai $\mathrm{pH}$ biji kopi akan cenderung naik sedangkan nilai $\mathrm{pH}$ air cenderung turun selama dan sesudah proses dekafeinasi berlangsung.

\subsection{Kadar Air}

Hasil analisa kadar air pada fermentasi perlakuan kontrol yaitu $1,21 \%$, perlakuan fermentasi 12 jam 1,88 \%, fermentasi 24 jam $1,76 \%$, fermentasi 36 jam 1,76\% dan untuk fermentasi 48 jam yaitu $2,36 \%$.

Hal ini menunjukkan bahwa kadar air meningkat seiring bertambahnya waktu fermentasi yang diberikan. Hasil analisa sidik ragam menunjukkan bahwa waktu fermentasi yang diberikan pada 
pembuatan kopi robusta yaitu berpengaruh nyata $(\mathrm{p}>0,05)$ terhadap kadar air.

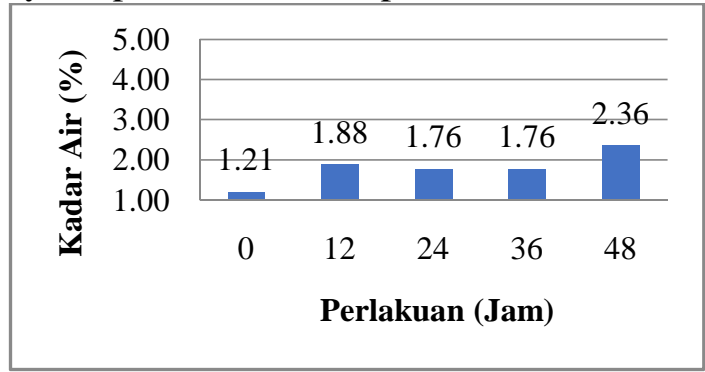

Gambar 6 Pengaruh Lama Fermentasi terhadap Kadar Air Kopi Robusta yang dihasilkan

Kadar air terendah yaitu pada kopi tanpa fermentasi (perlakuan kontrol). Sedangkan kadar air tertinggi yaitu pada kopi fermentasi selama 48 jam. Hal ini berkaitan dengan terserapnya air oleh poripori kopi pada saat proses fermentasi. Proses fermentasi yang lebih lama menyebabkan lebih banyak air yang terserap sehingga menyebabkan kadar air yang tinggi pada kopi yang difermentasi lebih lama. Hal ini sesuai dengan (Oktadina \& , Bambang dwi Argo, 2013), yang menyatakan bahwa Kadar air yang dihasilkan merupakan proses terikatnya dan masuknya air yang terdapat pada masingmasing komponen, sehingga air dapat diserap oleh pori-pori kopi ketika proses fermentasi berlangsung.

Menurut (Oktadina \& , Bambang dwi Argo, 2013), kadar air tinggi berpotensi terhadap umur simpan kopi bubuk. Akan tetapi hal tersebut dapat diminimalisasikan dengan cara pengolahan yang lebih baik lagi. Untuk kadar air yang rendah menghasilkan komponen lain yang tinggi. Terbukti bahwa kontrol yang tidak mengalami proses fermentasi menghasilkan kadar air yang rendah namun memiliki kafein yang tinggi.

\subsection{Kadar Abu}

Hasil analisa kadar air pada fermentasi perlakuan kontrol yaitu 3,44 \%, perlakuan fermentasi 12 jam 3,39 \%, fermentasi 24 jam 3,83\%, fermentasi 36 jam 3,59 \% dan untuk fermentasi 48 jam yaitu $3,16 \%$.
Hal ini menunjukkan bahwa kadar abu kopi robusta yang dihasilkan meningkat pada fermentasi selama 24 jam dan kemudian turun pada fermentasi 36 jam dan 48 jam.

Hasil analisa sidik ragam menunjukkan bahwa waktu fermentasi yang diberikan pada pembuatan kopi robusta yaitu berpengaruh nyata $(p<0,05)$ terhadap kadar abu. Setelah dilakukan uji lanjut Duncan, semua perlakuan berbeda nyata pada taraf $5 \%$.

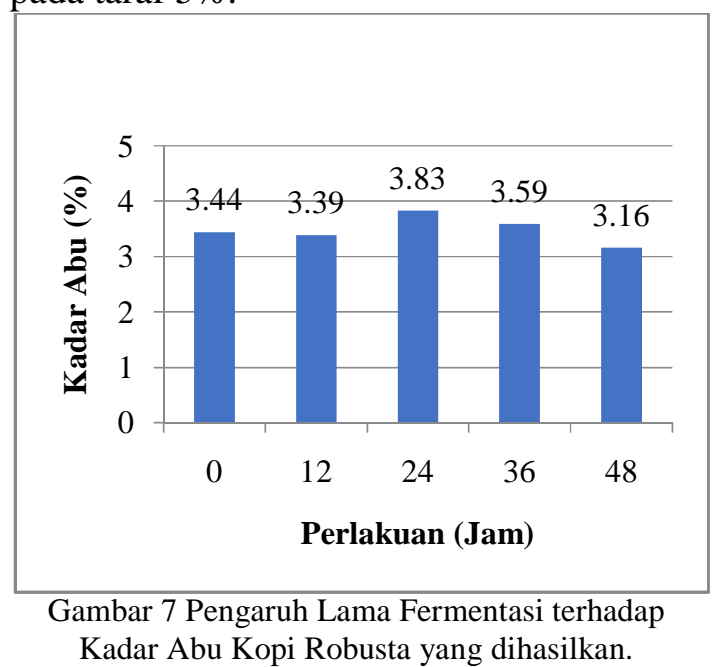

Hasil analisa kadar abu yang dihasilkan untuk semua sampel sesuai dengan syarat mutu kopi bubuk . Syarat kadar abu yang diizinkan untuk kopi bubuk yaitu $5 \%$ (Standar Perindustrian Indonesia, 1972).Kadar abu pada kopi robusta dengan menggunakan yogurt yang dihasilkan berkaitan dengan lama waktu fermentasi.

Kecepatan katalis enzim terhadap mineral-mineral pada kopi meningkat dengan lamanya waktu reaksi. Bahwa lama waktu kerja enzim mempengaruhi keaktifan enzim dalam mengkatalis reaksi pada mineral-mineral didalam kopi.

\section{KESIMPULAN}

Kesimpulan yang dapat diperoleh dari penelitian ini adalah sebagai berikut:

1. Semakin lama waktu fermentasi yang diberikan, maka mutu kopi semakin baik. Terlihat dari kadar kafein yang 
semakin menurun seiring dengan bertambahnya waktu fermentasi.

2. Hasil analisa kadar kafein pada fermentasi perlakuan kontrol yaitu $3,03 \%$, perlakuan fermentasi 12 jam $2,34 \%$, fermentasi 24 jam 1,93\%, fermentasi 36 jam 1,23\% dan untuk fermentasi 48 jam yaitu 1,09\%.

\section{DAFTAR PUSTAKA}

Charley, H. dan C. W. (1998). Foods (A Scientific Approach). New Jersey: Prentice hall Inc.

Hodgson, \& Levi. (1987). Modern Toxicology. Elseiver Science Publishing Co. Inc. New York.

Kristiyanto, D., \& Pranoto. (2013). Penurunan Kadar Kafein Kopi Arabika dengan Proses Fermentasi Menggunakan NOPKOR MZ-15. Jurnal Teknologi Kimia Dan Industri, 2(4).

Oktadina, F. D., \& , Bambang dwi Argo, \& M. B. H. (2013). Pemanfaatan Nanas ( Ananas Comosus L . Merr ) untuk Penurunan Kadar Kafein dan Perbaikan Citarasa Kopi ( Coffea Sp ) dalam Pembuatan Kopi Bubuk. Keteknikan Pertanian Tropis Dan Biosistem.

Sudarmadji, Haryono, S. B., \& Suhardi. (1997). Prosedur Analisis Bahan Makanan dan Pertanian. Yogyakarta: Liberty.

Winarno. (2004). Kimia Pangan dan Gizi. Jakarta: gramedia Pustaka Utama. 